\title{
Editorial
}

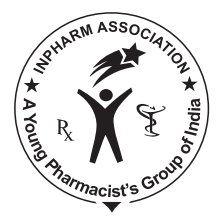

\section{Outgoing Editor's Message}

Over the last four years, we have witnessed significant growth of Journal of Young Pharmacists (JYP). Today, as an outgoing editor, it is my pleasure to introduce Dr. Parasuraman Subramani as the next Editor of the J Young Pharm. (1 ${ }^{\text {st }}$ April 2012 - 31 ${ }^{\text {st }}$ March 2015). Dr. Parasuraman is an outstanding researcher in the field of Pharmacology from JIPMER, Pondicherry, India. He has been serving InPharm in a number of capacities including as an Assistant Editor of the J Young Pharm and J Pharmacol Pharmacother during the last years. He is a young, talented, and energetic individual and has been identified for the editor post based on his active role in associated journals. With him as an editor-in-chief, the JYP will undoubtedly continue its tradition of excellence.

Over the last four years, we have witnessed significant growth of JYP in several aspects, starting from June 2009. Among them, the most impressive ones include the fact that we have increased article's quality. Based on the tool available at Medknow website, the projected impact factor for JYP (2011) is 0.342 as we are not yet indexed in Journal Citation reports to announce it officially. I am sure that soon JYP will be indexed with Science Citation Index and related databases. Other areas of growth for JYP include the expansion of scope to Indexing in PubMed, SCOPUS and many more.

During the past three years, I have had the unique privilege

\begin{tabular}{|l|l|}
\hline \multicolumn{2}{|c|}{ Access this article online } \\
\hline Quick Response Code: & \\
\hline & Website: \\
\hline & www.jyoungpharm.in \\
& DOI: \\
\hline
\end{tabular}

of working with outstanding Associate Editors, Guest Editors and Reviewers who served the Journal with remarkable diligence and commitment to quality. I feel a deep sense of gratitude to them for their efforts. I am grateful to Dr. DK Sahu (Former MD and Director, Medknow Publications and Media Pvt. Ltd., Mumbai, now as Wolter Kluwers Health and Medknow) and Medknow team for their flawless execution in the production of journal issue after issue, both in print and on the web.

I am highly indebted to the wonderful team of publication staff members, associate editors, for their dedicated services to select and publish extremely high quality papers for publication in JYP. My sincere thanks to all reviewers for their able untiring support to my request for the comments on submitted papers. Being the Editor-in-Chief of this esteemed journal is certainly one of the most rewarding experiences that an academician can hope for, and I am thankful to the InPharm Association for giving me this opportunity. I look forward to reading about exciting new developments under new leadership of Dr. Parasuraman in future issues of the journal.

I would also like to thank the authors for submitting their high quality papers to JYP and the readers for continued support to JYP by citing papers published in JYP. Without their continued and unselfish commitments, JYP would not have achieved its current status.

\section{Mueen Ahmed KK}

Editor-in-Chief, J. Young Pharm., Al-Ameen College of Pharmacy, Bangalore 560 027, India.

E-mail: mueen.ahmed@gmail.com

How to cite this article: Mueen Ahmed KK. Outgoing editor's message. J Young Pharmacists 2012;4:65. 